\title{
Vasoconstrictor responses in thromboxane receptor knockout mice: tubuloglomerular feedback and ureteral obstruction
}

\author{
J. SCHNERMANN, ${ }^{1}$ T. TRAYNOR, ${ }^{2} \mathrm{H}$. POHL, ${ }^{1}$ D.W. THOMAS,${ }^{3}$ \\ T.M. COFFMAN ${ }^{3}$ and J.P. BRIGGS ${ }^{1}$ \\ 1 National Institute of Diabetes, Digestive, and Kidney Diseases, NIH, Bethesda, MD, USA \\ 2 Department of Medicine, University of Michigan, Ann Arbor, MI, USA \\ 3 Department of Medicine, Duke University, Durham, North Carolina, USA
}

\begin{abstract}
The role of thromboxane (TP) in the vasoconstriction induced by tubuloglomerular feedback or 18-h ureteral obstruction was studied in wild type mice (TP +/+), and in heterozygous (TP +/-) and homozygous TP receptor knockout mice (TPR -/-). TGF function was assessed from the response of stop flow pressure $\left(P_{\mathrm{SF}}\right)$ to a maximum increase in loop of Henle flow rate $\left(0-30 \mathrm{~nL} \mathrm{~min}{ }^{-1}\right)$. $P_{\mathrm{SF}}$ fell by $6.4 \pm 0.4 \mathrm{mmHg}$ in wild-type mice, by $6.1 \pm 0.6 \mathrm{mmHg}$ in TP $+/-$, and by $7.9 \pm 0.7 \mathrm{mmHg}$ in TP $-/-$ mice. In the presence of the TP receptor agonist $U 46,619\left(10^{-5} \mathrm{M}\right)$ the $P_{\mathrm{SF}}$ reduction increased to $10.4 \pm 0.8 \mathrm{mmHg}$ in TP $+/+$, and to $10.6 \pm 2.8 \mathrm{mmHg}$ in TP $+/-$, but was unchanged at $7.7 \pm 0.7 \mathrm{mmHg}$ in TP $-/-$. Mean arterial blood pressures were comparable between groups (103 $\pm 3 \mathrm{mmHg}$ in TP $+/+, 113 \pm 4.6$ in TP $+/-$ and $113 \pm 2.4 \mathrm{mmHg}$ in TP $-/-$ mice). Intratubular pressure following unilateral ureteral obstruction was significantly higher in TP $-/-$ than in TP $+/+$ mice both in the early phase $(0-3 \mathrm{~h})$ and late phase (18 h) of obstruction. These results indicate that chronic TP receptor deficiency does not significantly alter maximum TGF responses in mice, and that it is accompanied by exaggerated vasodilatation during short-term unilateral ureteral obstruction and attenuated vasoconstriction during longer lasting obstruction. We conclude that thromboxane is primarily a regulator of renal vascular tone under pathophysiological conditions.
\end{abstract}

Keywords knockout mice, micropuncture, thromboxane, tubuloglomerular feedback, ureteral obstruction, vasoconstriction.

Received 27 September 1999, accepted 6 October 1999

The metabolism of arachidonic acid in the kidney by cyclooxygenases is associated with the production of prostanoid compounds that play a role in the local regulation of vascular resistance, tubular transport and hormone release (Breyer \& Badr 1996). Prostaglandin generation is a property of essentially all vascular and epithelial structures in the kidney, but the quantitative distribution within the prostaglandin spectrum is cellspecific. In the glomerular region, the major prostaglandins generated under physiological conditions are $\mathrm{PGE}_{2}$ and $\mathrm{PGI}_{2}$ while $\mathrm{PGF}_{2 \alpha}$ and thromboxane are produced at lower rates (Farman et al. 1987, Schlondorff \& Ardaillou 1986). While $\mathrm{PGE}_{2}$ and $\mathrm{PGI}_{2}$ have vasorelaxant properties, thromboxane $\mathrm{A}_{2}$ is a vasoconstrictor of most arteries and arterioles including the afferent arterioles of the glomerulus (Loutzenhiser et al.
1986). While the role of thromboxane in determining vascular tone under resting conditions in a normal kidney is probably small, there is considerable evidence to suggest that thromboxane importantly contributes to the vasoconstriction seen in a number of renal disease states (Remuzzi et al. 1992). For example, the increase in renal vascular resistance that develops during ureteral obstruction is to a major extent the consequence of increased production of thromboxane $\mathrm{A}_{2}$ (Morrison et al. 1977). Nevertheless, there is also evidence to indicate that thromboxane contributes to the vasoconstriction that results from an increase in $\mathrm{NaCl}$ concentration at the macula densa, the tubuloglomerular feedback response (Welch \& Wilcox 1988).

The recent generation of mice with a knockout mutation in the thromboxane prostanoid (TP) receptor 
gene has created a tool to assess the role of complete absence of functional TP receptors on renal vasoconstrictor responses in a new way (Thomas \& Coffman 1998, Thomas et al. 1998). TP receptor knockout mice show the expected abnormalities in coagulation time and platelet aggregation, but they are viable and phenotypically largely normal (Thomas et al. 1998). Notably, they do not seem to have a reduced blood pressure or an obvious alteration of renal function (Thomas et al. 1998). The current experiments were performed to investigate (1) if TP receptor knockout mice have a reduced tubuloglomerular feedback response as one would expect if thromboxane was an important constituent of the TGF constrictor pathway, and (2) if TP receptor knockout mice have a drastically altered vasoconstriction in response to ureteral obstruction. Our data indicate that chronic absence of TP receptors does not affect the TGF response magnitude, but that it has an attenuating effect on the vasoconstriction resulting from persistent ureteral obstruction.

\section{METHODS}

Experiments were performed in wild-type, heterozygous and homozygous mice of a strain carrying a null mutation in the TP receptor gene. Generation of mutant mice has been described by Thomas et al. (1998). Mice were genotyped by Southern blotting of tail DNA and maintained in the original colony at Duke University. Mice were fed a standard laboratory diet.

\section{Tubuloglomerular feedback studies}

Experiments were done in four wild type $(\mathrm{TP}+/+)$, three heterozygous (TP $+/-$ ), and four homozygous (TP $-/-$ ) mice of both sexes. Body and kidney weights averaged $30.7 \pm 4.7 \mathrm{~g}$ and $181.7 \pm 30.9 \mathrm{mg}$ in $\mathrm{TP}+/+$, $29.7 \pm 0.8 \mathrm{~g}$ and $183.3 \pm 8.3 \mathrm{mg}$ in $\mathrm{TP}+/-$, and $31.5 \pm 3.1 \mathrm{~g}$ and $194.2 \pm 11.7 \mathrm{mg}$ in $\mathrm{TP}-/-$ mice. Investigators were blinded as to the genotype of the animals. Animals were maintained on a standard rodent chow and tap water.

Mice were anaesthetized with $100 \mathrm{mg} \mathrm{kg}^{-1}$ inactin i.p. and $100 \mathrm{mg} \mathrm{kg}^{-1}$ ketamine intramuscularly. Body temperature was maintained at $38{ }^{\circ} \mathrm{C}$ by placing the animals on an operating table with a servo-controlled heating plate. The trachea was cannulated and a stream of $100 \%$ oxygen was blown towards the tracheal tube throughout the experiment. The femoral artery was cannulated with hand-drawn polyethylene tubing for measurement of arterial blood pressure. The femoral or jugular vein was cannulated for an intravenous maintenance infusion of $2.25 \mathrm{~g} \%$ bovine serum albumin in saline at a rate of $0.35 \mathrm{~mL} \mathrm{~h}^{-1}$. This rate of infusion has previously been shown to be associated with a urine flow around $2 \mu \mathrm{L} \mathrm{min}{ }^{-1}$ and a urine osmolarity around 1000 mosm kg$^{-1}$ (Schnermann et al. 1998) suggesting adequate hydration, but no overt volume expansion.

The left kidney was approached from a flank incision, freed of adherent fat and connective tissue, and placed in a lucite cup adapted for the size of the mouse kidney. The kidney was covered with mineral oil. Measurements of early proximal stop flow pressure $\left(P_{\mathrm{SF}}\right)$ during loop of Henle perfusion were done to assess tubuloglomerular feedback (TGF) responsiveness. A late proximal tubule segment was identified from the staining pattern following microperfusion of a randomly selected proximal segment with the FD\&C stained perfusate. The tubule was blocked with wax, the pump inserted in the last superficial proximal segment, and a pressure pipette connected to a servo null pressure device was inserted into an early proximal segment recognizable from the widening of the tubular lumen. When $P_{\mathrm{SF}}$ had stabilized, loop of Henle perfusion rate was altered between 30 and $0 \mathrm{~nL} \mathrm{~min}{ }^{-1}$ in a random fashion to assess maximum feedback responses. The perfusion pipette was then withdrawn, replaced with a pipette containing the TP receptor agonist U46,619 $\left(10^{-5} \mathrm{M}\right)$, and the TGF response to an increase in flow to $30 \mathrm{~nL} \mathrm{~min}{ }^{-1}$ was tested again. Perfusion fluid was artificial tubular fluid (ATF) containing (in $\mathrm{mmol} \mathrm{L}^{-1}$ ): $136 \mathrm{NaCl}, 4 \mathrm{NaHCO}_{3}, 4 \mathrm{KCl}, 2 \mathrm{CaCl}_{2}, 7.5$ urea, $100 \mathrm{mg}(100 \mathrm{~mL})^{-1}$ FD\&C green (Keystone) and $1 \mathrm{~g}(100 \mathrm{~mL})^{-1}$ ethanol as a solvent control. U46,619 was prepared as a $10^{-3} \mathrm{M}$ solution in ethanol and diluted 100-fold with ATF to yield a concentration of $10^{-5}$ M. U46,619-containing solutions were made fresh for each experiment. At the end of the experiments, the blood pressure responses to intravenous bolus injections of U46,619 were tested to functionally verify the animal's genotype.

\section{Ureteral obstruction}

The effect of an acute unilateral ureteral obstruction was studied in seven wild-type and seven homozygous TPR knockout mice. Four animals of each strain were used to examine the effect of acute ureteral obstruction on proximal tubular pressure. Animals were anaesthetized and prepared for micropuncture as described above. After determining proximal tubular pressures in several tubules the ureter was ligated close to the kidney. Measurements of tubular pressure were done over the next $3 \mathrm{~h}$ at a rate of 10-20 measurements per hour. Pressure measurements were averaged for the periods 0-30, 30-60, 60-120 and 120-180 min following ureteral ligation. Pressure was measured with a servo null pressure device (WPI, Sarasota, FL).

Three animals of each strain were anaesthetized with $70 \mathrm{mg} \mathrm{kg}^{-1}$ ketamine and $30 \mathrm{mg} \mathrm{kg}^{-1}$ xylazine given 
Table 1 Tubuloglomerular feedback responses in wild-type, heterozygous and homozygous thromboxane receptor (TPR) knockout mice and effect of tubular application of the thromboxane agonist U46,619 $\left(10^{-5} \mathrm{M}\right)$ on the response magnitude

\begin{tabular}{|c|c|c|c|c|c|c|c|}
\hline & \multirow[b]{2}{*}{$\begin{array}{l}\text { Mice/ } \\
\text { tubules }\end{array}$} & \multicolumn{3}{|l|}{ Control } & \multicolumn{3}{|l|}{ U46,619 } \\
\hline & & $\mathrm{nL} \min ^{-1}$ & $\begin{array}{l}30 \\
\mathrm{~nL} \min ^{-1}\end{array}$ & $\begin{array}{l}\text { MAP } \\
(\mathrm{mmHg})\end{array}$ & $\begin{array}{l}0 \\
\mathrm{~nL} \min ^{-1}\end{array}$ & $\begin{array}{l}30 \\
\mathrm{~nL} \min ^{-1}\end{array}$ & $\begin{array}{l}\text { MAP } \\
(\mathrm{mmHg})\end{array}$ \\
\hline $\mathrm{TPR}+/+$ & $4 / 15$ & $41.9 \pm 1.6$ & $35.5 \pm 1.4$ & $103.1 \pm 2.9$ & $43.4 \pm 1.7$ & $33.0 \pm 1.8$ & $103.1 \pm 3.0$ \\
\hline TPR +/- & $3 / 8$ & $41.8 \pm 1.7$ & $35.7 \pm 1.3$ & $113.2 \pm 4.6$ & $44.1 \pm 2.5$ & $35.1 \pm 1.8$ & $113.3 \pm 4.6$ \\
\hline TPR -/- & $4 / 13$ & $46.0 \pm 1.9$ & $38.1 \pm 1.8$ & $113.6 \pm 2.6$ & $45.2 \pm 1.6$ & $37.5 \pm 1.7$ & $112.7 \pm 2.4$ \\
\hline
\end{tabular}

intraperitoneally. The left ureter was ligated, and the abdominal incision sutured. $18 \mathrm{~h}$ later the animals were prepared for micropuncture as described above and 10-15 measurements of proximal tubular pressures were performed using different tubules for each measurement.

Statistical comparisons were made with ANOVA in association with the Scheffe test, or the Student $t$-test, using paired or unpaired comparisons, as appropriate.

\section{RESULTS}

\section{Tubuloglomerular feedback studies}

Results from these studies are summarized in Table 1. Mean arterial blood pressures in the three groups of rats were not different although there was a tendency for blood pressure to be slightly higher in TP $-/-$ mice than in wild-type animals. Similarly, stop flow pressures $\left(P_{\mathrm{SF}}\right)$ at zero flow were not significantly different and averaged $41.9 \pm 1.6 \quad(n=15), \quad 41.8 \pm 1.7 \quad(n=8)$ and $46.0 \pm 1.9 \mathrm{mmHg}(n=13)$ in $\mathrm{TP}+/+$, $\mathrm{TP}+/-$, and $\mathrm{TP}-/-$, respectively. When flow was increased to $30 \mathrm{~nL} \mathrm{m^{-1 }} P_{\mathrm{SF}}$ fell to $35.5 \pm 1.4 \mathrm{mmHg}$ in $\mathrm{TP}+/+$, to $35.7 \pm 1.3 \mathrm{mmHg}$ in $\mathrm{TP}+/-$, and to $38.1 \pm 1.8$ in TP $-/-$ mice. As can be seen in Fig. 1 maximum TGF responses were not significantly different between the different TP receptor genotypes.

The effect of luminal perfusion with the TP receptor agonist $\mathrm{U} 46,619$ was performed to verify the absence of functional receptors in the region of the glomerulus in the TP knockout mice. Data in Table 1 and Fig. 1 show that U46,619 significantly enhanced TGF responses in wild-type animals (from $6.4 \pm 0.4$ to $10.4 \pm 0.8$ $\mathrm{mmHg} ; \quad P=0.0005$ ) and in $\mathrm{TP}+/-$ mice (from $6.1 \pm 0.6$ to $10.6 \pm 2.8 \mathrm{mmHg} ; P=0.0005)$ whereas no effect was seen in TP $-/-$ mice $(7.9 \pm 0.7$ vs. $7.7 \pm 0.7 \mathrm{mmHg})$. An original recording of the $P_{\mathrm{SF}}$ changes in response to flow elevations with and without $\mathrm{U} 46,619$ in $\mathrm{TP}+/+$ and $\mathrm{TP}-/-$ mice is shown in Fig. 2.

Measurements of mean arterial blood pressure in response to intravenous bolus injections of U46,619 are shown in Fig. 3. Injections of $10-60 \mu \mathrm{g} \mathrm{kg}^{-1}$ U46,619 caused increases in blood pressure by 15

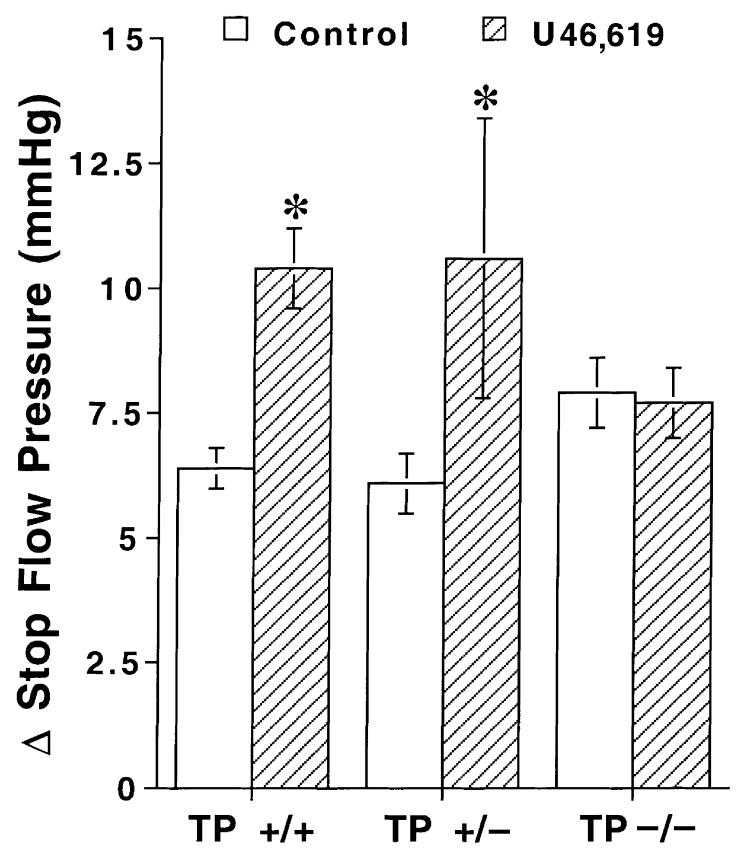

Figure 1 Mean stop flow pressure changes in $\mathrm{TP}+/+$, $\mathrm{TP}+/-$ and TP -/ - mice during loop perfusion with Ringer solution without (control) and with the TP receptor agonist U46,619 $\left(10^{-5} \mathrm{M}\right)$. Vertical bars are SE. * Significance at $P<0.05$ compared with control perfusion.

$20 \mathrm{mmHg}$ in $\mathrm{TP}+/+$ and $\mathrm{TP}+/-$ mice. The application of higher doses led to very transient blood pressure increases followed by pronounced reductions in blood pressure that were usually irreversible. In contrast, in TP -/- animals U46,619 in doses up to $2 \mathrm{mg} \mathrm{kg}{ }^{-1}$ had only minimal effects on blood pressure and was tolerated without noticeable haemodynamic deterioration.

\section{Ureteral obstruction}

Measurements of tubular pressure in $\mathrm{TP}+/+$ and TP $-/-$ are summarized in Fig. 4. It can be seen that tubular pressures before obstruction were not different between TP $+/+$ and TPR $-/-$ animals $(16.5 \pm 1.09$ and $18.1 \pm 1.31 \mathrm{mmHg}$, respectively). Tubular pressure 


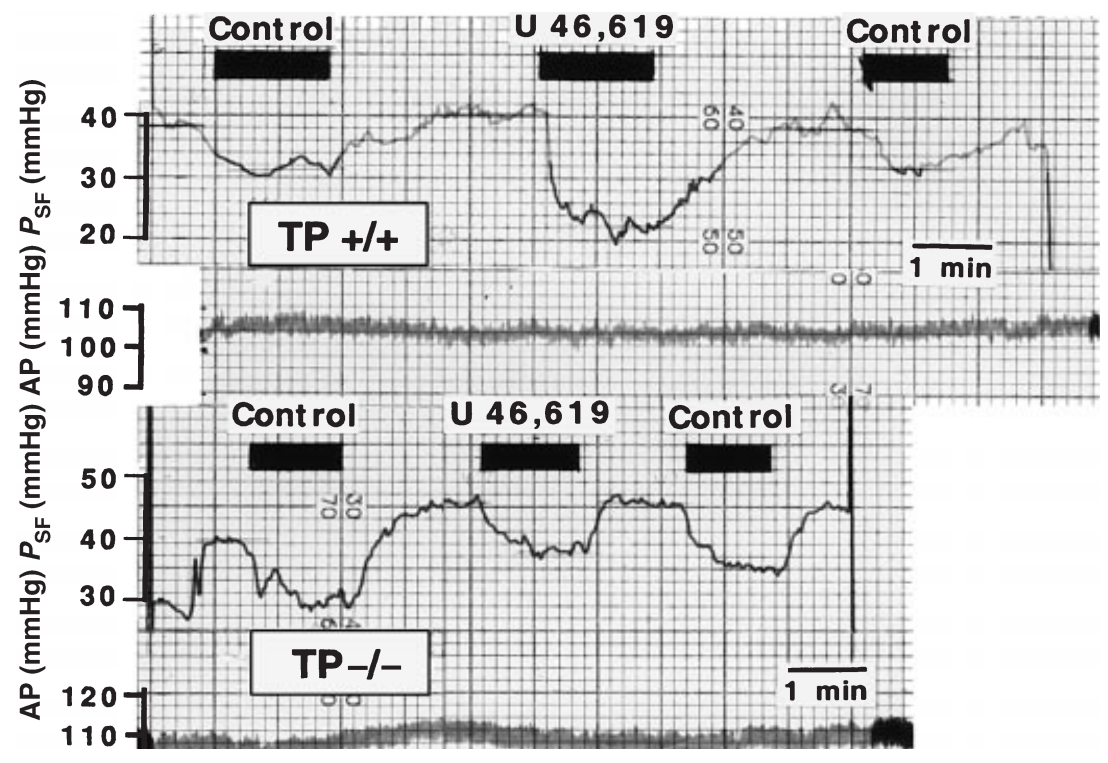

Figure 2 Original recording of stop flow pressure ( $P_{\mathrm{SF}}$, upper tracings) and arterial pressure (AP, lower tracings) in a wild-type $(\mathrm{TP}+/+)$ and homozygous TP knockout mouse (TP -/-) during loop perfusion without (control) and with TP agonist (U46,619). Periods of loop perfusion at $30 \mathrm{~nL} \mathrm{~min}^{-1}$ are indicated by black boxes.

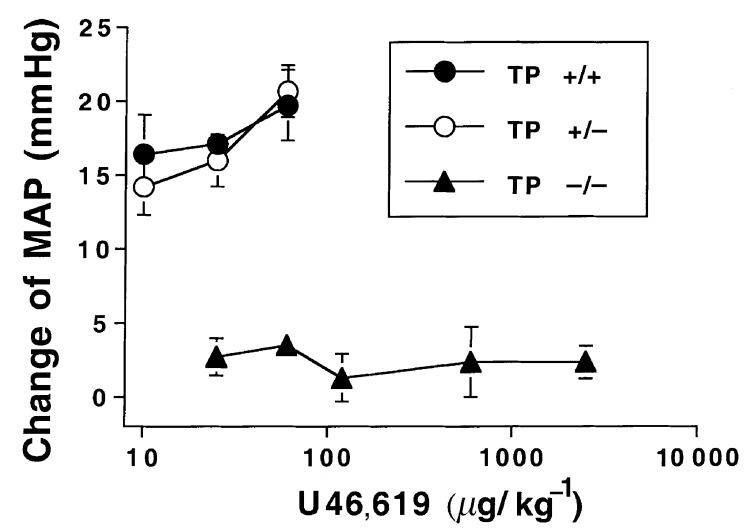

Figure 3 Changes in mean arterial blood pressure (MAP) in wild-type $(\mathrm{TP}+/+)$, heterozygous $(\mathrm{TP}+/-)$ and homozygous thromboxane receptor (TP -/-) knockout mice during intravenous bolus injections of the TP receptor agonist U46,619. Bars indicate SE.

increased following ureteral obstruction in both strains of mice, but reached higher levels in TP $-/-$ mice. Differences in tubular pressure between $\mathrm{TP}+/+$ and TP -/- were significant at time points longer than $30 \mathrm{~min}$ following obstruction. Measurements of tubular pressure performed $18 \mathrm{~h}$ after unilateral ureteral obstruction showed the previously described return to essentially normal values in TP $+/+$ mice $(16.5 \pm 1.06$ vs. $17.9 \pm 0.24 \mathrm{mmHg} ; P=0.31)$. In contrast, tubular pressure remained significantly higher than control in TP -/- animals $(18.1 \pm 1.3$ vs. $24.7 \pm 0.67 \mathrm{mmHg}$, respectively; $P=0.01)$. Blood pressure of $\mathrm{TP}+/+$ and TPR $-/-$ mice during these experiments are shown in Fig. 5. It can be seen that blood pressure levels in the acute studies were slightly, although not significantly higher in $\mathrm{TP}-/-$ than in $\mathrm{TP}+/+$ mice.

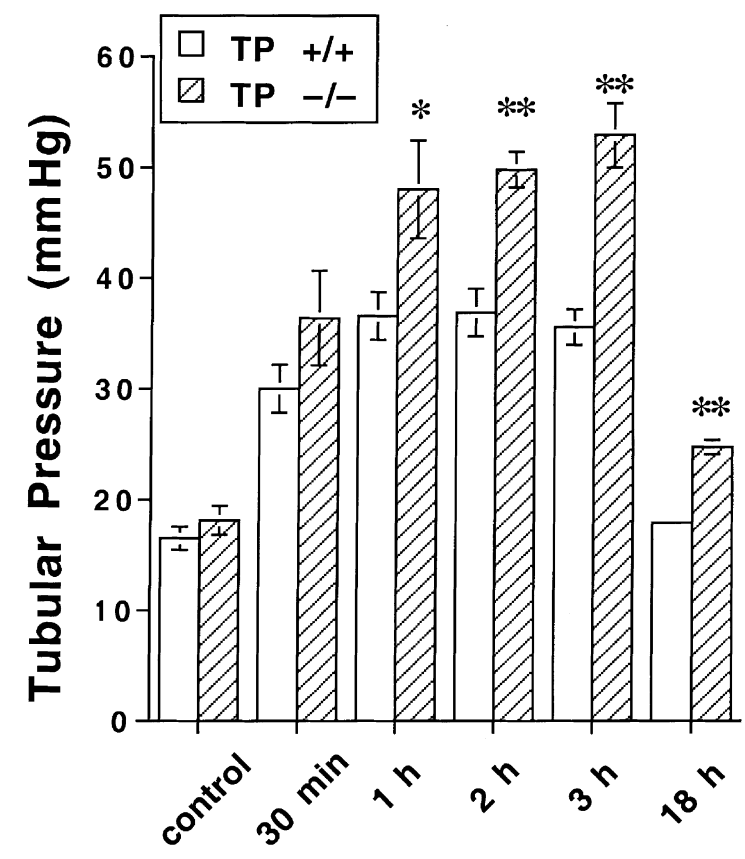

Figure 4 Time dependency of change in tubular pressure following ureteral obstruction in wild-type $(\mathrm{TP}+/+)$ and homozygous thromboxane receptor (TPR -/-) knockout mice. Values are means and bars indicate SE. $* P<0.05$, ** $P<0.01$ (compared with TPR $+/+$ ).

\section{DISCUSSION}

The current experiments were performed in mice with a knockout mutation in the TP receptor gene for a further elucidation of the role of thromboxane in renal vasoconstriction. Absence of functional TP receptors in these mice has been verified previously by demonstrating absent expression of TP receptor mRNA in thymocytes and lack of TP agonist binding in renal 


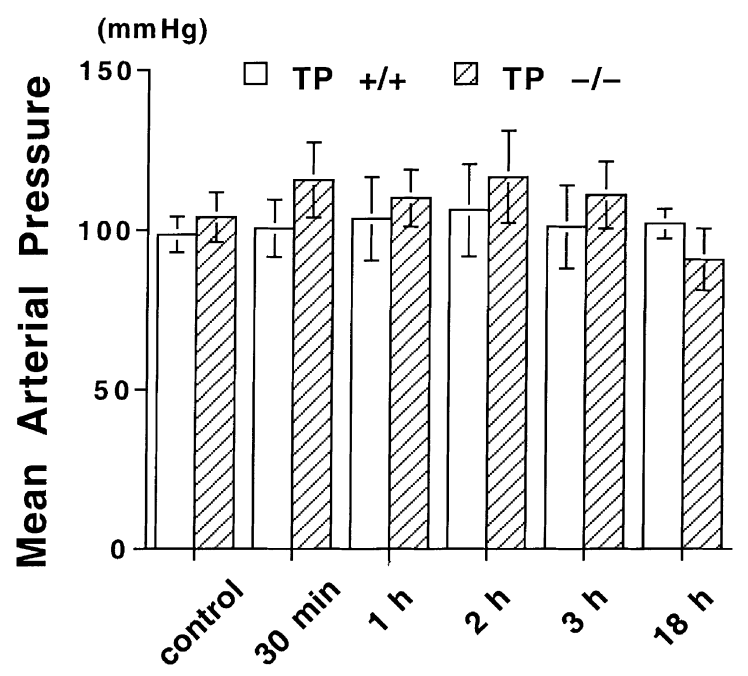

Figure 5 Mean arterial blood pressure in wild-type $(\mathrm{TP}+/+)$ and homozygous thromboxane receptor $(\mathrm{TP}-/-)$ knockout mice before and during different times of unilateral ureteral obstruction. Values are means and bars indicate SE.

cortex and medulla (Thomas et al. 1998). Lack of TP receptors is also consistent with the resistance of TP -/ - mice to bolus injections of the TP receptor agonist U46,619 in doses that cause marked blood pressure reductions and death in wild-type animals. This haemodynamic collapse that has also been observed in a previous study is presumably the consequence of platelet aggregation and subsequent thrombotic events (Thomas et al. 1998).

The present studies of the TGF system in TP receptor knockout mice show that TGF responses to a saturating increase of macula densa $\mathrm{NaCl}$ concentration are not significantly altered in TP $-/-$ animals compared with $\mathrm{TP}+/+$ or $\mathrm{TP}+/-$ mice. On the basis of previous studies in rats during acute pharmacological inhibition of TP receptors or TP synthesis we had expected a reduction in maximum TGF response magnitude in the TP -/- animals (Morsing et al. 1989, Welch \& Wilcox 1988, 1990). However, the effect of interference with the action of thromboxane on TGF responses is sometimes relatively small (Franco et al. 1988, Morsing et al. 1989, Brannstrom \& Arendshorst 1999), and it is possible that we were unable to detect a small difference owing to the necessarily non-paired design of our experiments. On the other hand, the contribution to the TGF vasoconstrictor response seen under acute conditions of TP receptor inhibition may not be evident when TP receptors are chronically nonfunctional. It has been suggested that acute TP receptor inhibition may affect TGF in part by a reduction in $\mathrm{NaCl}$ transport, an effect that one may expect to be compensated during prolonged removal of TP influences (Welch \& Wilcox 1992). The cause for the absence of clear differences between TP $-/-$ and $\mathrm{TP}+/+$ mice does not seem to be related to absence of a capacity for TP receptors to modulate TGF in the wild type animals as an enhancement of TGF responses was observed with local application of the TP agonist U46,619. This is consistent with earlier micropuncture studies in rats (Welch \& Wilcox 1992, Welch et al. 1997) and with the regular observation of abundant expression of TP receptors in the glomerular region of various species including mice (Asano et al. 1996, Bresnahan et al. 1996, Takahashi et al. 1996). It seems reasonable to assume that the effects of TP under normal conditions are limited by low expression of TP synthase and TP production rates (Farman et al. 1987, Endoh et al. 1997, Tsutsumi et al. 1997). It is also possible that the production of vasorelaxant prostaglandins from the same pool of arachidonic acid balances the constrictor actions of TP activation. In general, TP receptor inhibition does not measurably affect renal functional parameters such as renal blood flow and glomerular filtration rate (Purkerson et al. 1986, Jackson et al. 1988, Welch \& Wilcox 1990). This further supports the notion that the effects of thromboxane on renal vascular resistance under non-stressed conditions in the healthy kidney are marginal.

Numerous studies have shown that both unilateral and bilateral ureteral obstruction initially cause a vasodilator response that is followed by a progressive and persistent vasoconstriction (Klahr \& Harris 1992). The most direct evidence for this biphasic response came from measurements of renal blood flow in the dog showing that kidneys are hyperperfused for 2 to $3 \mathrm{~h}$ followed by progressive reductions in blood flow such that at times longer than $18 \mathrm{~h}$ renal blood flow is reduced to half the control value (Moody et al. 1975). The biphasic profile in renal blood flow following unilateral ureteral obstruction is mimicked by parallel changes in intratubular pressure showing an initial rise followed by a reduction to normal values by $18 \mathrm{~h}$ or longer (Dal Canton et al. 1979). The change in renal blood flow is caused by inverse changes in renal vascular resistance with the vasomotor response being predominantly located in the afferent arterioles (Dal Canton et al. 1979, Klahr \& Harris 1992).

There is evidence that angiotensin II and thromboxane acting in concert are responsible for the vasoconstriction of afferent arterioles elicited by ureteral obstruction (Klahr \& Harris 1992). The present finding that intratubular pressure after $18 \mathrm{~h}$ of ureteral obstruction was significantly higher in the TP $-/-$ mice than in control is in agreement with this notion. Changes of intratubular pressure under conditions of complete ureteral obstruction have been shown to parallel changes of tubular stop flow pressure (Arendshorst et al. 1974, Persson et al. 1984, Tanner 
1985) and therefore can serve as an index of glomerular capillary pressure. Thus, the greater rise in tubular pressure in the TP $-/-$ mice suggests that thromboxane formed in response to ureteral obstruction acts to counteract the full extent of the initial vasodilator response to obstruction. Increased formation of thromboxane during ureteral obstruction has been well documented in previous studies (Morrison et al. 1977, Klahr \& Harris 1992). After 18 h of ureteral obstruction intratubular pressure in $\mathrm{TP}+/+$ mice had returned to control in agreement with earlier observations (Arendshorst et al. 1974, Dal Canton et al. 1979, Persson et al. 1984, Tanner 1985, Klahr \& Harris 1992). Tubular pressure in TP $-/-$ mice at $18 \mathrm{~h}$ had also fallen significantly compared with the acute phase, but it remained higher than in wild-type animals. Thus while TP-induced vasoconstriction appears to be responsible for some of the reduction in intratubular pressure other vasoconstrictor mechanism(s) operate to prevent persistent increases in tubular pressure.

In summary, the current experiments show that TGF responses to maximum flow stimulation are identical between wild-type and homozygous TP receptor knockout mice suggesting that chronic alterations in TP receptor expression and TP formation are unlikely to regulate TGF response magnitude and/ or TGF sensitivity. The role of thromboxane as a regulator of vascular tone under physiological conditions studied may be limited. On the other hand, TP receptor deficiency is accompanied by exaggerated vasodilatation during short-term unilateral ureteral obstruction and attenuated vasoconstriction during longer lasting obstruction, consistent with the notion that thromboxane participates in the vascular response to ureteral occlusion.

This work was supported by National Institutes of Health Grants DK 37448, DK 39255, and DK 40042 and grants from the Research Service of the Department of Veterans' Affairs.

\section{REFERENCES}

Arendshorst, W.J., Finn, W.F. \& Gottschalk, C.W. 1974. Nephron stop-flow pressure response to obstruction for 24 hours in the rat kidney. J Clin Invest 53, 1497-1500.

Asano, K., Taniguchi, S., Nakao, A., Maruyama, T., Watanabe, T. \& Kurokawa, K. 1996. Distribution of thromboxane A2 receptor mRNA along the mouse nephron segments.

Biochem Biophys Res Commun 226, 613-617.

Brannstrom, K. \& Arendshorst, W.J. 1999. Thromboxane A2 contributes to the enhanced tubuloglomerular feedback activity in young SHR. Am J Physiol 276, F758-F766.

Bresnahan, B.A., Le Breton, G.C. \& Lianos, E.A. 1996. Localization of authentic thromboxane A2/prostaglandin H2 receptor in the rat kidney. Kidney Int 49, 1207-1213.
Breyer, M. \& Badr, K.F. 1996. Arachidonic acid metabolites and the kidney. In: B.M. Brenner (ed.), The Kidney, Vol. I, pp. 754-788. W.B. Saunders Company, Philadelphia.

Dal Canton, A., Corradi, A., Stanziale, R., Maruccio, G. \& Migone, L. 1979. Effects of 24-hour ureteral obstruction on glomerular hemodynamics in rat kidney. Kidney Int 15, 457-462.

Endoh, M., Kashem, A., Yamauchi, F. et al. 1997. Expression of thromboxane synthase in kidney tissues from patients with IgA nephropathy. Clin Nephrol 47, 168-175.

Farman, N., Pradelles, P. \& Bonvalet, J.P. 1987. PGE 2 , $\mathrm{PGF}_{2 \alpha}, \mathrm{PGF}_{1 \alpha}$, and $\mathrm{TXB}_{2}$ synthesis along the rabbit nephron. Am J Physiol 252, F53-F59.

Franco, M., Bell, P.D. \& Navar, L.G. 1988. Evaluation of prostaglandins as mediators of tubuloglomerular feedback. Am J Physiol 254, F642-F649.

Jackson, E.K., Goto, F., Uderman, H.D. et al. 1988. Effects of thromboxane synthase inhibitors on renal function. Naunyn-Schmiedeberg's Arch Pharmacol 337, 183-190.

Klahr, S. \& Harris, K.P.G. 1992. Obstructive nephropathy. In: D.W. Seldin \& G. Giebisch (ed), The Kidney, Physiology and Pathophysiology, Vol. 3, pp. 3327-3369. Raven Press, New York.

Loutzenhiser, R., Epstein, M., Horton, C. \& Sonke, P. 1986. Reversal of renal and smooth muscle actions of the thromboxane mimetic U-46609 by diltiazem. Am J Physiol 250, F619-F626.

Moody, T.E., Vaughn, E.D. \& Gillenwater, J.Y. 1975. Relationship between renal blood flow and ureteral pressure during 18 hours of total unilateral uretheral occlusion. Implications for changing sites of increased renal resistance. Invest Urol 13, 246-251.

Morrison, A.R., Nishikawa, K. \& Needleman, P. 1977. Unmasking of thromboxane $A_{2}$ synthesis by ureteral obstruction in the rabbit kidney. Nature 267, 259-260.

Morsing, P., Stenberg, A. \& Persson, A.E. 1989. Effect of thromboxane inhibition on tubuloglomerular feedback in hydronephrotic kidneys. Kidney Int 36, 447-452.

Persson, A.E., Wahlberg, J., Safirstein, R. \& Wright, F.S. 1984. The effect of 2 hours of complete unilateral ureteral obstruction on tubuloglomerular feedback control. Acta Physiol Scand 122, 35-43.

Purkerson, M.L., Martin, K.J., Yates, J., Kissane, J.M. \& Klahr, S. 1986. Thromboxane synthesis and blood pressure in spontaneously hypertensive rats. Hypertension 8, 1113-1120.

Remuzzi, G., FitzGerald, G.A. \& Patrono, C. 1992. Thromboxane synthesis and action within the kidney. Kidney Int 41, 1483-1493.

Schlondorff, D. \& Ardaillou, R. 1986. Prostglandins and other arachidonic acid metabolites in the kidney. Kidney Int 29, 108-119.

Schnermann, J., Chou, C.-L., Ma, T., Traynor, T., Knepper, M.A. \& Verkman, A.S. 1998. Defective proximal tubular fluid reabsorption in transgenic aquaporin-1 null mice. Proc Natl Acad Sci 95, 9660-9664.

Takahashi, N., Takeuchi, K., Abe, T., Sugawara, A. \& Abe, K. 1996. Immunolocalization of rat thromboxane receptor in the kidney. Endocrinology 137, 5170-5173. 
Tanner, G.A. 1985. Tubuloglomerular feedback after nephron or ureteral obstruction. Am J Physiol 248, F688-F697.

Thomas, D.W. \& Coffman, T.M. 1998. A genetic approach for studying the role of thromboxane A2 in the kidney. Kidney Int 54 (Suppl 67), S84-S87.

Thomas, D.W., Mannon, R.B., Mannon, P.J. et al. 1998. Coagulation defects and altered hemodynamic responses in mice lacking receptors for thromboxane A2.J Clin Invest 102, 1994-2001.

Tsutsumi, E., Takeuchi, K., Abe, T. et al. 1997. Rat kidney thromboxane synthase: cDNA cloning and gene expression regulation in hydronephrotic kidney. Prostaglandins 53, 423-431.
Welch, W.J., Peng, B., Takeuchi, K., Abe, K. \& Wilcox, C.S. 1997. Salt loading enhances rat renal TxA2/PGH2 receptor expression and TGF response to U-46,619. Am J Physiol 273, F976-F983.

Welch, W.J. \& Wilcox, C.S. 1988. Modulating role for thromboxane in the tubuloglomerular feedback response in the rat. J Clin Invest 81, 1843-1849.

Welch, W.J. \& Wilcox, C.S. 1990. Feedback responses during sequential inhibition of angiotensin and thromboxane. Am J Physiol 258, F457-F466.

Welch, W.J. \& Wilcox, C.S. 1992. Potentiation of tubuloglomerular feedback in the rat by thromboxane mimetic. Role of macula densa. J Clin Invest 89, 1857-1865. 